\title{
PENETAPAN KADAR KADMIUM (Cd) DALAM RUMPUT LAUT MERAH (Eucheuma spinosum) PERAIRAN PANTAI DI KECAMATAN BANGKALA KABUPATEN JENEPONTO
}

\author{
Rahmawati $^{1)}$, Hasnah ${ }^{1)}$, Widya Ashari Nur ${ }^{1)}$ \\ ${ }^{1)}$ Program Studi DIII Teknologi Laboratorium Medis Politeknik Kesehatan Muhammadiyah \\ Makassar \\ Alamat korenspondensi: rahmawatiamma60@gmail.com
}

\begin{abstract}
Abstrak
Kadmium (Cd) adalah metal berbentuk kristal putih keperakan. Logam kadmium merupakan salah satu jenis logam berat yang berbahaya karena logam ini beresiko tinggi terhadap pembuluh darah. Selain itu, akibat paparan $C d$ dalam tubuh manusia dalam jangka waktu panjang dapat terakumulasi pada organ seperti hati dan ginjal. Penelitian ini bertujuan untuk menentukan kadar logam kadmium (Cd) pada rumput laut merah (Eucheuma spinosum) di perairan pantai Kabupaten Jeneponto. Jenis penelitian ini yaitu observasi laboratorik dengan melakukan uji kuantitatif menggunakan metode Spektrofotometer Serapan Atom (SSA) dan sampel ditentukan dengan teknik purposive sampling. Dari hasil penelitian ini menunjukkan bahwa 6 sampel yang telah diteliti memiliki kadar kadmium (Cd) yaitu pada sampel A sebesar 20.903 ppm, sampel B sebesar 29.770 ppm, sampel C sebesar 21.802 ppm, sampel D sebesar 14.964 ppm, sampel E sebesar 16.187 ppm, sampel F sebesar 13.347 ppm. Berdasarkan hasil penelitian dapat disimpulkan bahawa sampel yang telah di teliti memiliki kadar kadmium (Cd) yang melebihi ambang batas normal 0,005 ppm yang telah ditetapkan oleh permenkes No. 416/Menkes/Per/IX/1990.
\end{abstract}

Kata Kunci: Kadmium (Cd), Rumput Laut Merah, Sepektrofotometer Serapan Atom (SSA)

\section{PENDAHULUAN}

Salah satu sumber daya hayati yang cukup potensial dari perairan laut Indonesia adalah rumput laut dengan berbagai macam jenisnya. Rumput laut (seaweed) adalah tumbuhan laut yang tergolong dalam ganggang (alga) multiseluler divisi Thallophyta tidak seperti tanaman sempurna pada umumnya, rumput laut tidak memiliki akar, batang, dan daun (Atmadja, 2012). Jenis rumput laut yang mempunyai nilai ekonomis dan sudah banyak dibudidayakan secara intensif di wilayah pesisir dikenal dengan Euchema spinosum. Kabupaten Jeneponto merupakan salah satu daerah di Sulawesi Selatan yang memiliki potensi kelautan dan kawasan pesisir, khususnya di Kecamatan Bangkala.

Rumput laut hidup di dalam air laut sedangkan di dalam air laut dan air tawar terkandung beberapa mineral dan logam berat pencemaran akibat kegiatan industri dan buangan limbah yang mengandung zat beracun. Salah satu pencemaran pada badan air adalah masuknya ion logam berat. Peningkatan kadar logam berat di dalam perairan akan diikuti oleh peningkatan kadar zat tersebut dalam organisme air seperti kerang, rumput laut dan biota laut lainnya. Pemanfaatan organisme ini sebagai bahan makanan akan membahayakan kesehatan manusia (Mukhtasor, 2007).

Kandungan logam berat di perairan mendapat perhatian yang cukup besar bagi para ahli toksikologi. Beberapa logam berat seperti $\mathrm{Cu}, \mathrm{Fe}$, dan $\mathrm{Zn}$ merupakan komponen penting untuk pertumbuhan organisme, tetapi dalam jumlah besar dapat menjadi racun bagi pertumbuhannya. Jenis logam berat lainnya seperti $\mathrm{Cd}, \mathrm{Hg}$, dan $\mathrm{Pb}$ belum 
diketahui manfaatnya bagi pertumbuhan organisme, bahkan keberadaan logam tersebut dapat menggantikan logam berat yang dibutuhkan oleh organisme. Interaksi logam berat dengan bahan organik yang terkandung di perairan atau proses metilasi oleh biota akan mempengaruhi tingkat keracunan logam berat tersebut (Haryoto dan Agustono, 2004).

Logam berat yang mencemari lingkungan perairan salah satunya yaitu kadmium (Cd) (Teheni dan Syamsidar, 2013). Pencemaran akibat aktivitas manusia lebih banyak berpengaruh dibandingkan pencemaran secara alami. Contohnya ialah transportasi laut yang menggunakan bahan bakar dan limbah domestik yang dapat menghasilkan logam Kadmium (Cd) yang dapat mencemari air laut. Kadmium (Cd) banyak terdapat dalam air buangan industri terutama industri elektroplating atau metalurgi dan industri yang menggunakan logam sebagai bahan baku proses serta industri yang menggunakan logam sebagai bahan baku proses serta industri logam non ferrous yang menghasilkan abu, uap, air limbah dan endapan yang mengandung Cd. Keberadaan Kadmium (Cd) ini dalam air buangan sangat berpotensi mencemari lingkungan (Sony, 2009).

Berdasarkan penelitian yang telah dilakukan oleh Betawi (2012), diperoleh hasil bahwa kadar logam kadmium pada rumput laut merah di Kabupaten Takalar 0, 305 ppm telah melewati ambang batas. Kadmium adalah metal berbentuk kristal putih keperakan. Logam kadmium merupakan salah satu jenis logam berat yang berbahaya karena logam ini beresiko tinggi terhadap pembuluh darah. Selain itu, akibat paparan $\mathrm{Cd}$ dalam tubuh manusia dalam jangka waktu panjang dapat terakumulasi pada organ seperti hati dan ginjal (Kurniawan, 2010).

Kandungan logam berat kadmium yang ada pada perairan berdasarkan permenkes No. 416/Menkes/Per/IX/1990
Nilai Ambang Batas (NAB) Kadar Kadmium yang ada dalam air yaitu sebesar 0,005 ppm. Berdasarkan uraian diatas, maka tujuan penelitian yaitu untuk menetukan kadar kadmium (Cd) pada rumput laut merah (Eucheuma spinosum) di Kabupaten Jeneponto.

\section{METODE PENELITIAN \\ Alat dan Bahan}

Alat-alat yang digunakan dalam penelitian ini meliputi neraca analitik, hotplate, erlenmeyer, labu ukur, gelas kimia, pipet tetes, batang pengaduk, cawan petri, corong, dan Spektrofotometer serapan atom.

Bahan-bahan penelitian ini adalah rumput laut merah (Euchema spinosum), aquadest, $\mathrm{HNO}_{3}$ pekat, larutan induk kadmium $(\mathrm{Cd})$, kertas saring.

\section{Persiapan Sampel}

Sampel rumput laut diambil di pesisir perairan Kecamatan Bangkala Kabupatan Jeneponto pada titik pengambilan sampel sebanyak 6 titik. Pengambilan sampel rumput laut dilakukan secara langsung menggunakan kantong plastik kemudian dimasukkan ke dalam botol. Sampel dibersihkan dari material pengotor dengan menggunakan air mengalir dan dibilas dengan aquadest, kemudian dikeringkan dalam oven pada suhu $60^{\circ} \mathrm{C}$ sampai berubah menjadi coklat kehitaman. Sampel yang sudah kering kemudian dihancurkan menjadi serbuk dan dihomogenisasi dalam lumpang dengan mortar.

\section{Pembuatan Kurva Kalibrasi Kadmium} (Cd)

Kurva kalibrasi logam Cd diperoleh dengan membuat larutan standar dengan beberapa variasi konsentrasi. Logam $\mathrm{Cd}$ pada konsentrasi $0,1,2,3,4$ dan 5 ppm. Lalu diukur serapan larutan standar masing-masing logam pada kondisi optimum. Kemudian, dibuat kurva antara konsentrasi terhadap serapan masing-masing logam. 


\section{Pengujian Sampel Untuk Analisis Logam}

Masing-masing rumput laut ditimbang sebanyak 2,5 gram dimasukkan ke dalam Erlenmeyer, ditambahkan 10 $\mathrm{mL} \mathrm{HNO}_{3}$ pekat, kemudian dipanaskan perlahan-lahan sampai volume mencapai 5-10 mL. Penambahan asam dan pemanasan terus dilakukan sampai semua logam larut, yang terlihat dari warna endapan dalam uji menjadi agak putih atau menjadi jernih. Kemudian didinginkan dan dimasukkan kedalam gelas kimia dan diencerkan dengan aquadest sampai tanda batas $50 \mathrm{~mL}$, diaduk kemudian disaring filtratnya, dan ditampung dalam botol sampel.

\section{HASIL DAN PEMBAHASAN}

Berdasaran hasil penelitian yang telah dilakukan terhadap sampel rumput laut merah (Eucheuma spinosum) diperoleh hasil sebagai berikut:

Tabel 1. Hasil pengukuran kadar kadmium (Cd) pada rumput laut merah

\begin{tabular}{ccc}
\hline $\begin{array}{c}\text { Kode } \\
\text { Sampel }\end{array}$ & Satuan & $\begin{array}{c}\text { Kadar } \\
\text { Kadmium }\end{array}$ \\
\hline A & ppm & 20,92 \\
B & ppm & 29,77 \\
C & ppm & 21,78 \\
D & ppm & 14,57 \\
E & ppm & 16,19 \\
F & ppm & 13,34 \\
\hline
\end{tabular}

Pada tabel 1. hasil penelitian menunjukan bahwa logam berat Kadmium terdeteksi pada semua sampel rumput laut merah yang dianalisis dengan metode Spektrofotometer Serapan Atom (SSA). Dari hasil penelitian sebanyak 6 sampel diperoleh kadar Kadmium yang melebihi ambang batas normal 0,005 ppm yang telah ditetapkan oleh permenkes No. 416/Menkes/Per/IX/1990.

Pada penelitian ini preparasi sampel dilakukan dengan menggunakan metode destruksi. Destruksi berfungsi untuk memutuskan ikatan antara senyawa organik dengan logam yang akan dianalisa agar yang tertinggal hanya logam. Destruksi yang digunakan adalah dekstruksi basah karena dapat menentukan unsur logam dengan konsentrasi yang rendah.

Proses dekstruksi basah pada penelitian ini dilakukan dengan cara rumput laut dalam erlenmeyer ditambahkan $\mathrm{HNO}_{3}(\mathrm{P})$ kemudian di panaskan di dalam ruangan asam. $\mathrm{HNO}_{3}(\mathrm{P})$ bertujuan untuk memecahkan sampel menjadi senyawa yang mudah terurai, sedangkan pemanasan pada proses ini untuk mempercepat proses pemutusan ikatan logam, pada proses ini akan membawa perubahan warna uap dari kuning kecoklatan menjadi putih. Setelah proses destruksi sempurna, lalu dinginkan, kemudian hasil destruksi di encerkan dengan aquadest. Selanjutnya pembacaan hasil dengan menggunakan alat Spektrofotometri Serapan Atom (SSA).

Hasil penelitian ini menunjukkan bahwa 6 sampel yang telah di teliti memiliki kadar kadmium (Cd) yang melebihi ambang batas normal 0,005 ppm yang telah ditetapkan oleh permenkes No. 416/Menkes/Per/IX/1990 yaitu pada sampel A sebesar 20.92 ppm, sampel B sebesar $29.77 \mathrm{ppm}$, sampel C sebesar $21.78 \mathrm{ppm}$, sampel D sebesar $14.57 \mathrm{ppm}$, sampel E sebesar 16.19 ppm, sampel F sebesar 13.34 ppm.

Rumput laut merah (Eucheuma spinosum) memiliki kemampuan menghasilkan senyawa fungsional terutama agarofit dan karaginofit. Umumnya kandungan nutrisi rumput laut sangat bervariasi karena di pengaruhi oleh faktor musim, lokasi geografi tempat tumbuh (habitat), jenis spesies, umur panen,dan kondisi lingkungan. Selain itu banyak factor yang bisa menyebabkan akumulasi logam berat yang salah satunya dalam badan perairan dapat berasal dari sumber-sumber alamiah dan dari aktivitas manusia. Hal ini dapat menyebabkan semakin lama pemaparan maka semakin banyak logam berat khususnya kadmium 
(Cd) yang terakumulasi dalam thallus rumput laut. Pencemaran akibat aktivitas manusia lebih banyak berpengaruh dibandingkan pencemaran secara alami. Contohnya ialah transportasi laut yang menggunakan bahan bakar dan limbah domestik yang dapat menghasilkan logam Kadmium (Cd) yang dapat mencemari air laut.

Kadmium (Cd) banyak terdapat dalam air buangan industri terutama industri yang berasal dari PLTU yang terdapat di daerah bangkala. Limbahlimbah yang dihasilkan dipantai akan masuk kedalam perairan sehingga dapat mengganggu kehidupan organisme didalamnya. Keberadaan Kadmium (Cd) ini dalam air buangan sangat berpotensi mencemari lingkungan. Logam berat $\mathrm{Cd}$ dalam badan perairan akan mengalami proses akumulasi dalam tubuh biota yang ada, kemampuan biota untuk menimbun logam (bioakumulasi) melalui rantai makanan. Sehingga, terjadi metabolisme bahan berbahaya secara biologi dan akan mempengaruhi organisme yang ada di perairan. Sehingga kandungan logam dalam tubuh organisme dipengaruhi oleh tinggi rendahnya tingkat pencemaran (Darmono, 1995).

Kandungan logam berat kadmium yang ada pada perairan berdasarkan permenkes No. 416/Menkes/Per/IX/1990 Nilai Ambang Batas (NAB) Kadar Kadmium yang ada dalam air yaitu sebesar 0,005 ppm. Apabila logam kadmium yang ada pada perairan melebihi ambang batas maka logam ini beresiko tinggi terhadap pembuluh darah. Efek toksik dari logam Cd mampu menghalangi kerja enzim sehingga dapat mengganggu metabolisme tubuh. Selain itu, akibat paparan $\mathrm{Cd}$ dalam tubuh manusia dalam jangka waktu panjang dapat terakumulasi pada organ seperti hati dan ginjal. Kadmium dalam tubuh manusia sebagian besar diperoleh melalui pencernaan dan dapat terakumulasi pada ginjal sehingga mengalami disfungsi (Dewi, 2011).

\section{KESIMPULAN}

Berdasarkan hasil penelitian yang telah dilakukan, maka dapat disimpulkan bahwa dari 6 sampel yang telah di teliti memiliki kadar kadmium (Cd) yang melebihi ambang batas normal 0,005 ppm yang telah ditetapkan oleh permenkes No. 416/Menkes/Per/IX/1990 yaitu pada sampel A sebesar 20.903 ppm, sampel B sebesar $29.770 \mathrm{ppm}$, sampel C sebesar $21.802 \mathrm{ppm}$, sampel D sebesar 14.964 ppm, sampel E sebesar 16.187 ppm, sampel F sebesar 13.347 ppm.

\section{DAFTAR PUSTAKA}

Atmadja, W., S. 2012. Apa Rumput Laut Itu Sebenarnya?. Diunduh pada tanggal 12 Maret 2020 dari http://www.coremap.or.id/print/arti cle.php?id=264.

Betawi. S. A. 2012. Analisis Kadar Logam Kadmium (Cd) yang teradsorpsi pada rumput laut merah (Eucheuma Cottoni) di kabupaten takalar dengan metode spektrofotometer serapan atom (SSA). Skripsi. Fakultas Sains Dan Teknologi UIN Alauddin Makassar.

Darmono. 1995. Logam Dalam Sistim Biologi Mahluk Hidup. Universitas Perss. Jakarta.

Dewi. 2011. Analisis Cemaran Logam Timbal $(\mathrm{Pb})$, Tembaga $(\mathrm{Cu})$, dan Kadmium (Cd) Dalam Tepung Gandum Secara Spektrofotometri Serapan Atom. Skripsi. Jakarta: FMIPA Program Studi Farmasi Universitas Indonesia.

Haryoto dan Agustono W. 2004. Kinetika Bioakumulasi Logam Berat Kadmium oleh Fitoplankton Chlorella sp Lingkungan Perairan Laut. Jurnal Penelitian Sains \& Teknologi. 5 (2) : 89-103.

Kurniawan, A. 2010. Mineral Kadmium. Universitas Dipenogoro. Semarang

Mukhtasor. 2007. Pencemaran Pesisir dan Laut. PT. Pradnya Paramita. Jakarta. 
Palar, H. 2008. Pencemaran dan Toksikologi Logam Berat. Bandung: Rineka Cipta.

Rusmiati, D. 2011. Uji Aktifitas Antibakteri Etanol Rumput Laut. Bandung: Universitas Padjajaran.

Sony, 2009. Penentuan Kadar Logam Seng ( $\mathrm{Zn})$ dan Tembaga (Cu) Dalam Air Pam Hasil Penyaringan Yamaha Water Purifier Tipe Drinking Stand. Skripsi. Medan: FMIPA Program Studi Kimia Universitas Sumatera Utara. Medan.

Teheni, M. T. dan Syamsidar, H.S. 2013. Penentuan Kadar Dan Distribusi Spasial Logam Berat Kadmium (Cd) Pada Rumput Laut Eucheuma cottoni Asal Perairan Kabupaten Takalar dengan Metode Spektrofotometri Serapan Atom. Al-Kimia. 1 (1): 30-41 